\title{
The effectiveness of agrarian cooperation in the issues of food safety and economic growth in the country
}

\author{
N. Rukhaia-Mosemgvdlishvili \\ David Agmashenebeli National Defense Academy,Georgia \\ This work was supported by Shota Rustaveli National Science Foundation (SRNSF) YS-2016- \\ 23 Young Scientists Research Grant.
}

\begin{abstract}
In this paper we discuss ways of cooperation in agrarian sector and it's role in developing the field and stimulating export, based on example of small developing country, Georgia. During last year, using secondary and empirical studies, we have studied difficulties in Georgian agrarian sector, corresponding problems and different ways of their solution proposed to government by scientists. We also studied farmer's positions regarding those solutions, because no matter how many laws are written in the government creating effective models for the development, it is crucial to have powerful teams who have great desire, knowledge and experience for participation and implementation of the plan. Unfortunately, today there is no such commitment. This is confirmed by the fact that all existing projects enjoy support, are existing farmers who have already had their own businesses and wanted to expand. Theoretically, on the one hand, it is not as bad, probably good; however, real outcome can be achieved only with the large scale effect; therefore, all miniagricultural lands should be involved in agricultural production. In this article we focus on how farmers see and approach different ways of cooperation, mass export and regional development. At the end, propose our vision how we should stimulate those people to get involved in modern agrarian production, which at the end will play substantial role in boosting Georgia's economy by increasing both GPD and export coefficient.
\end{abstract}

\section{Introduction}

The role of exports in the country's economic development is doubtless to anyone; we believe that the growing negative balance of Georgia in international trade is the matter of concern to any Georgian economist. According to the comparative advantages Georgia can become competitive in the field of agricultural production by its produce. Production of competitive products will result in the efficient use of resources, obtaining domestic and international market share, increasing the welfare effects of the population.

It is essential to have a target market for export-oriented enterprises development. Georgian agricultural products have their consumers and are well known through the CIS member countries; these are inertial markets which have been maintained since the USSR collapse. However, due to current political situation, these markets are unsteady. Consequently, the issue for the necessity of expanding the economy arises. We strongly believe that such kind of opportunity is the agreement signed with the EU Association and a deep and comprehensive EU Free Trade Agreement which not only allows the country to new markets, but also facilitates financial support for the development of the field. It is essential to allow the spending of the amount in the right direction within coordinated policy framework in order to obtain real development of the sector and not a temporary effect.

It is noticeable that recently in the agricultural sector the government has been significantly enhanced which is a positive trend and thus it increases the urgency of this thesis. Today Georgian agricultural sector is in such condition that its stimulation to development is available with only thoughtfully and properly selected complex agricultural policy. Moreover, the signing of the Association Agreement with the European Union and a deep and comprehensive Free Trade Agreement have originated the theoretical possibility of a rise in Georgia's economy and penetration through the European market. 
Studies have shown that recently the Georgian agricultural space requires overall structural changes in order to make it more efficient and profit-oriented farmers' community. We think that for the Georgian economy the most appropriate and optimal model is agriculture oriented on the export of food industry products.

Consequently, it is important that agricultural policy would include not only agricultural and farming development strategies, but also be an integral part of regional policy.

No matter how many laws are written in the government creating effective models for the development, it is crucial to have a powerful team who have great desire, knowledge and experience for participation and implementation of the plan. Unfortunately, today there is no such commitment. This is confirmed by the fact that all existing projects enjoy support, i.e. existing farmers who have already had their own businesses wanted to expand existing ones. Theoretically, on the one hand, it is not as bad, probably good; however, real outcome can be achieved only with the large scale effect; therefore, all mini-agricultural lands should be involved in agricultural production. The biggest problem in Georgian agricultural sector is fragmental patches of land, where practically is impossible to carry out profitable economic activities. Relevantly establishing various forms and development of farmers' cooperation should be an essential component of the agricultural policy.

Existence of sales market plays a significant role in stimulating the production. At present, the structure of exports by country Azerbaijan and Armenia are leaders at the expense of re-export of vehicles, which, unfortunately, has been taking "honorary" first place in the structure of the Georgian exports. Unfortunately, we were not able to obtain the Information about the real exported volume of agricultural produce of Georgia by country. On the other hand, the fact is that $50 \%$ of the country's exports falls on the CIS countries whose sales market is the most irresponsible and unstable in the current political and conflict situations.

Accordingly, the necessity for further market development and expansion arises to ensure stable markets. EU Association Agreement and DFCHA regime is likely the opportunity.

Certainly, we are not able to export the products promptly to the European Union, the proof of it is the statistics of recent years; therefore it is necessary compliance with European standards and customer-oriented production development. European consumers are aware of the product quality standards and in result, with the growing living conditions the demand for organic food products rises. This is not so quickly digestible market as resource for growing organic produce is limited. However, it may become a competitive advantage for our country.

Growing living standards and infrastructure to the regions are necessary conditions, without which all other reforms remain meaningless, as it just will not have the target segment. Nowadays, in the villages "aging" process is sharply observed. Young people cannot stay in the regions, where there are no elementary conditions for living, household and entertainment facilities. In result, the young are moving to regional centers, especially to the capital. So, Tbilisi has turned into a giant megapolis where almost $40 \%$ of Georgia's population live and the rest in emptied regions.

\section{The aim of research}

Georgian agricultural production, processing and export related problems analysis, in particular, revealing the sectors (products) that have the most of the export potential. In addition, it is important as well to select the estimated export countries (markets), study and formation of the measures necessary for providing capital to the sector; the study of other countries model and the analysis of possible application of their experience in Georgian reality. Regarding the purposes for the study, the following tasks have been outlined:

1. The agricultural sector the major recognized problem- detection of decapitalisation tools; detection of drawing attention for banking, finance and insurance sector and analysis of the current problems in the banking sector, possible interest for 'Start-up' businesses. In the 21st century the main tool for sector capitalization is to supply the sector with investors, 
and provide with credits by financial institutions. Today, in Georgia very few financial institutions are interested in investing in the agricultural sector; however, the guarantee system is used against this problem by the state. The aim of the study is to figure out new, innovative ideas in the field of development and reveal novative solutions for attracting funds.

2. The survey of main workforce- peasants and farmers in field and rural areas, their attitudes and opinions analysis.

This study gave us the information about the mood of the population, the analysis of their problems assist us in determining the principle messages of PR campaign while economic policy formation. In addition, it is possible to identify a new type of challenges and opportunities; Research trips in the regions were continued throughout the period of the study, and include all the regions.

3. Consultations with the owners of the medium and large farms, processing plants, as well as farmers' associations in the agricultural sector and non-governmental organizations in order to identify today's real problems in the field.

Business activity is a good indicator of the economic problems. Those consultations will be most informative for unveiling existing faults and barriers at legislative and public policy levels and finding real ways for solving them.

4. The Government's recent past, the results of the examination of agricultural projects. The main difficulties and barriers to reveal.There is no secondary data about mentioned items and have not been carried out fundamental scientific research. As a result of this research, we get very valuable information on how to respond effectively to the farmers and the government's initiatives; which component of the projects were carried out effectively and how it was used in Georgian reality. Researching the real reasons for the projects causing "weak spots" will facilitate to observe the problems beyond the facts and reveal the factors that hinder the effective implementation of these projects.

\section{Research Outcomes}

Within the scope of the study, with random survey 500 farmers were interviewed in all regions of Georgia.

There are the major findings of the study:

- There is a big difference between the farmers, who have the access to internet and the one, who has not. We received totally different responses from internet-based survey and from paper-based survey in the respondent with the same age and income. (Questions were the same in both surveys).

- People in regions, which has no connection with internet, think, that they have enough knowledge to harvest, but government is bad and don't helps them to sell the product. They don't have enough information about government support programs and are not use them. Don't see the importance of the new technologies and as a rule, they are harvesting the ancestral land.

- Respondents, who answered by internet are more interested in new technologies, new knowledge. They are interested in export of their product. Are not asking for government subsidiaries. They have good information about governmental support programs, are using them and have their experience about them.

- Cooperation system does not work in Georgia, because there are not enough interested people. Also, there are a lot of people, who has earned the one, but they did not get eny profit from it.

Here are few charts from the survey: 
$8^{\text {th }}$ International Conference on Management, Economics and Humanities

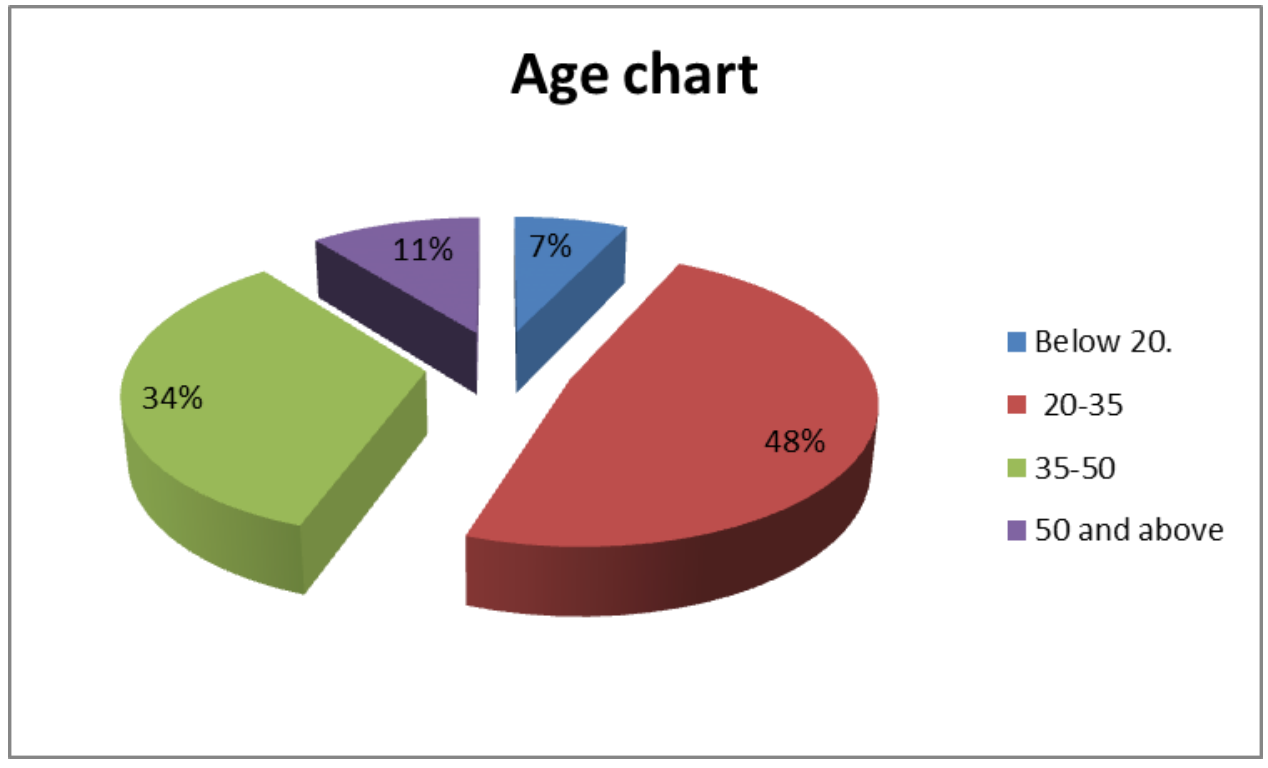

\section{To which directions of agriculture is your business focused?}

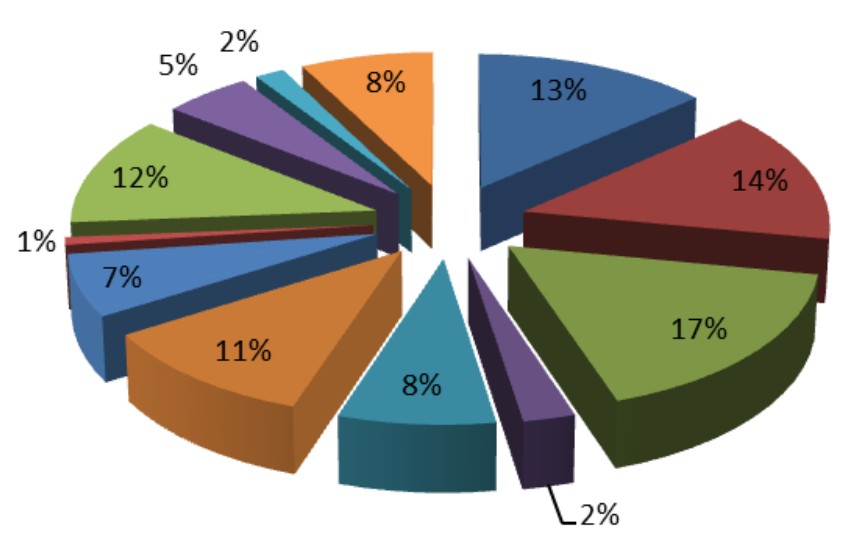

Winery

- Processing of agricultural products

- Production of nut / walnut / fist

Breeding

- Poultry

cultivating tea

Grain-growing

- Production of berry crops 
$8^{\text {th }}$ International Conference on Management, Economics and Humanities

\section{How long have you been doing agrarian activities?}

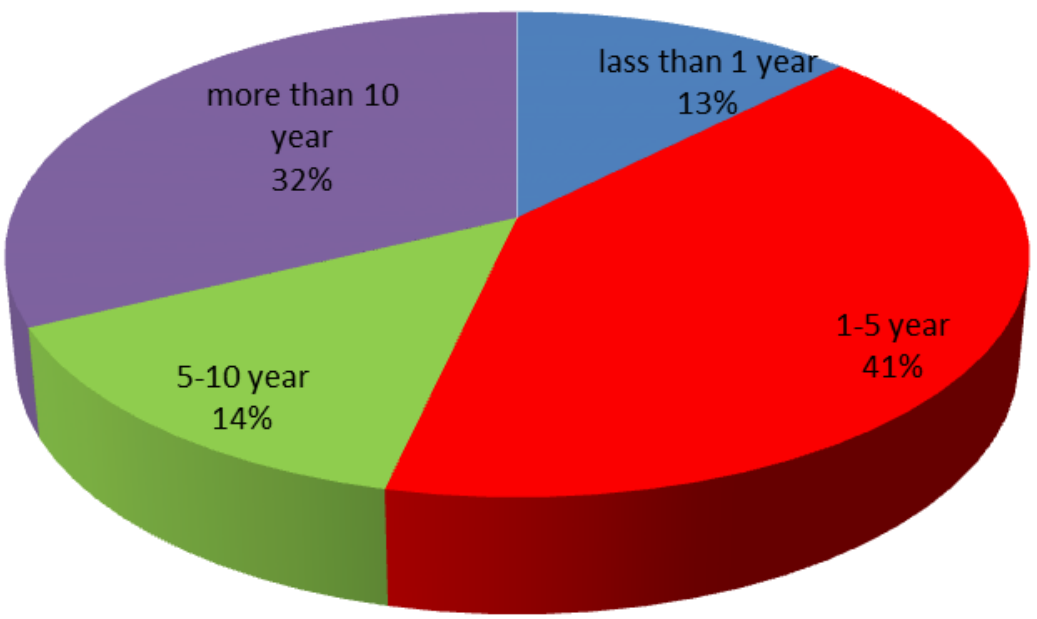

\section{Evaluate your involvement:}
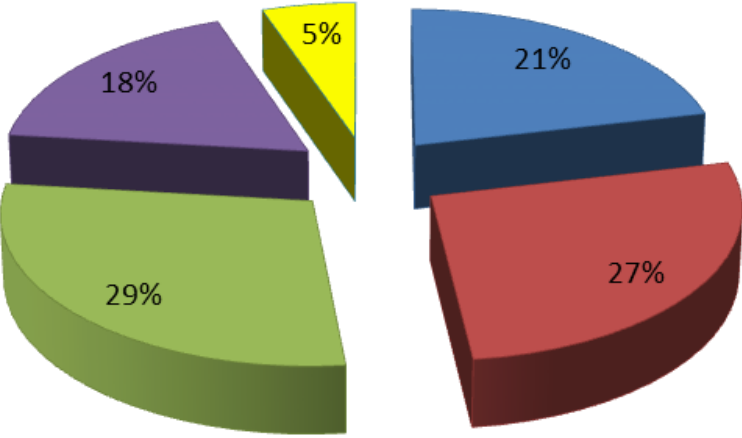

I produce mainly for my own use, and occasionally sell extra harvest in small quantities.

- I have small agrarian production, which isn"t enough to descently support myself so I need extra income.

$\square \mathrm{I}$ am begginer farmer and I hope to get profit from my investition in couple of years.

I I have succesful family business, which provides not much, but descent income.

$\square$ I have succesful agrobusiness and I use hired workforce. 
As the research shows, most part of the people, who are involved in agrarian business and fill themselves as farmers and are working for profit, are persons from Tbilisi (or at least live there last few years). They do farming from distance. They have other job and in non-working hours taking care for their agrarian business. This segment of our respondents was more look like independent business man. They say, they don't need some special subsidiary from government, they are ready and want to study new technologies and will be happy if government will cover their eexpenses in this case. But it is important, that they also are not a part of agricultural cooperatives. And, if they are, they are not satisfied with the results of their cooperation. Here are some results about cooperation:

\section{Are you a member of cooperative union?}

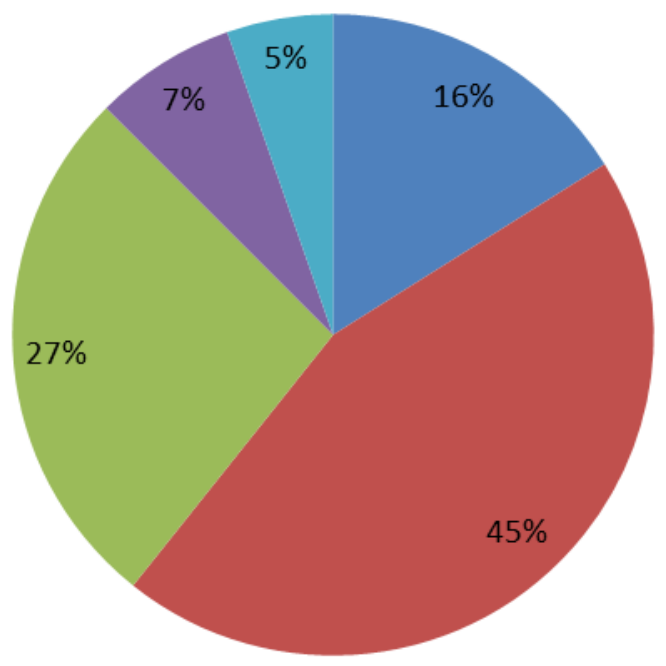

No, I have had enough of cooperatives in Soviet Union.

- I want to particiapte, but no one in the surroundings is willing to.

- I don"t see any advantage in it.

I am participating and using goverment benefits for it.

- I am participating but don"t see any advantage in it.

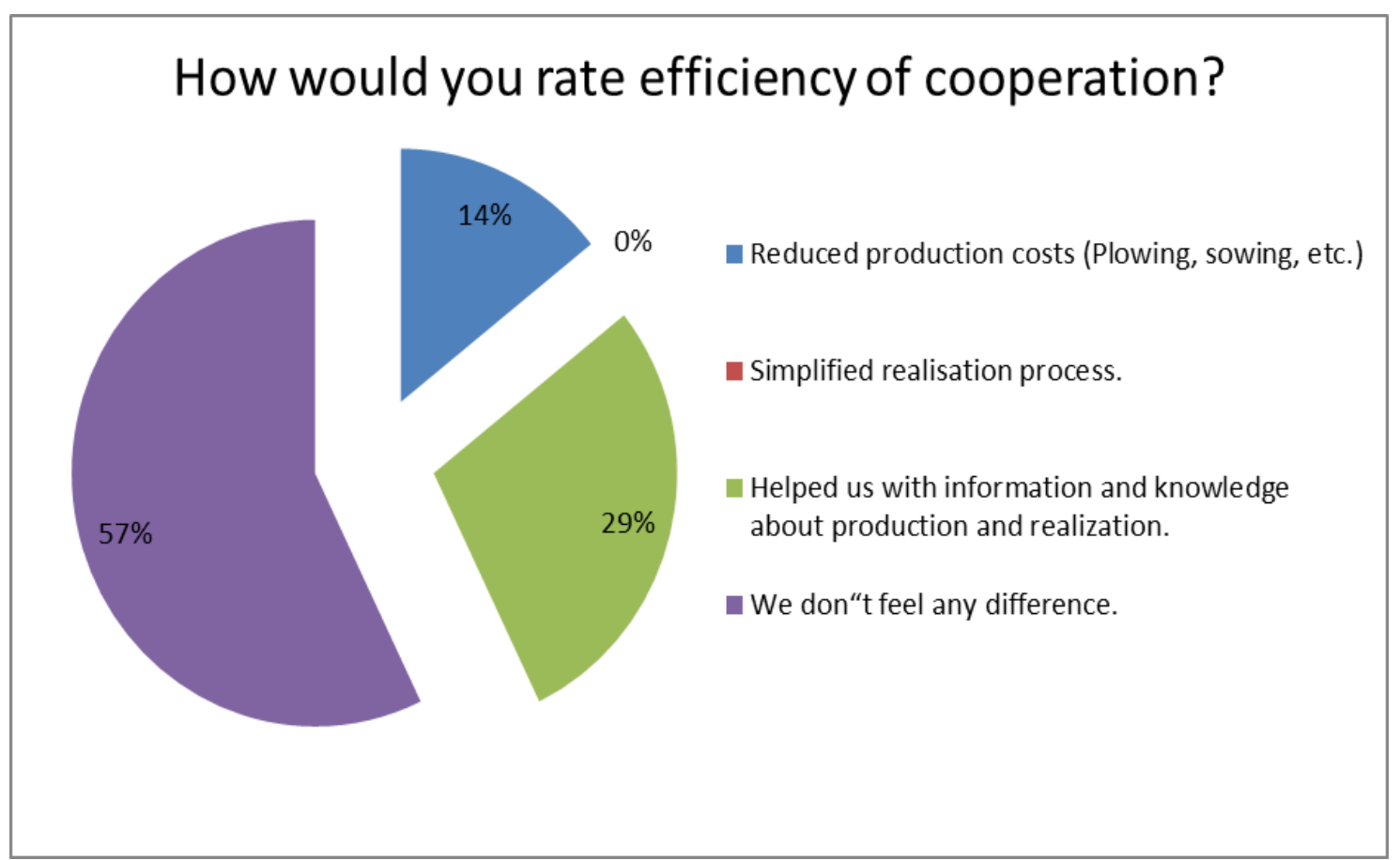


$8^{\text {th }}$ International Conference on Management, Economics and

Humanities

7 - 9 December, 2018

Barcelona, Spain

These results show that the government program in populating cooperation in agricultural field was not successful. Besides, there are few cooperatives, which are working and receiving profits.

Another interesting case is using modern technologies and web for their business:

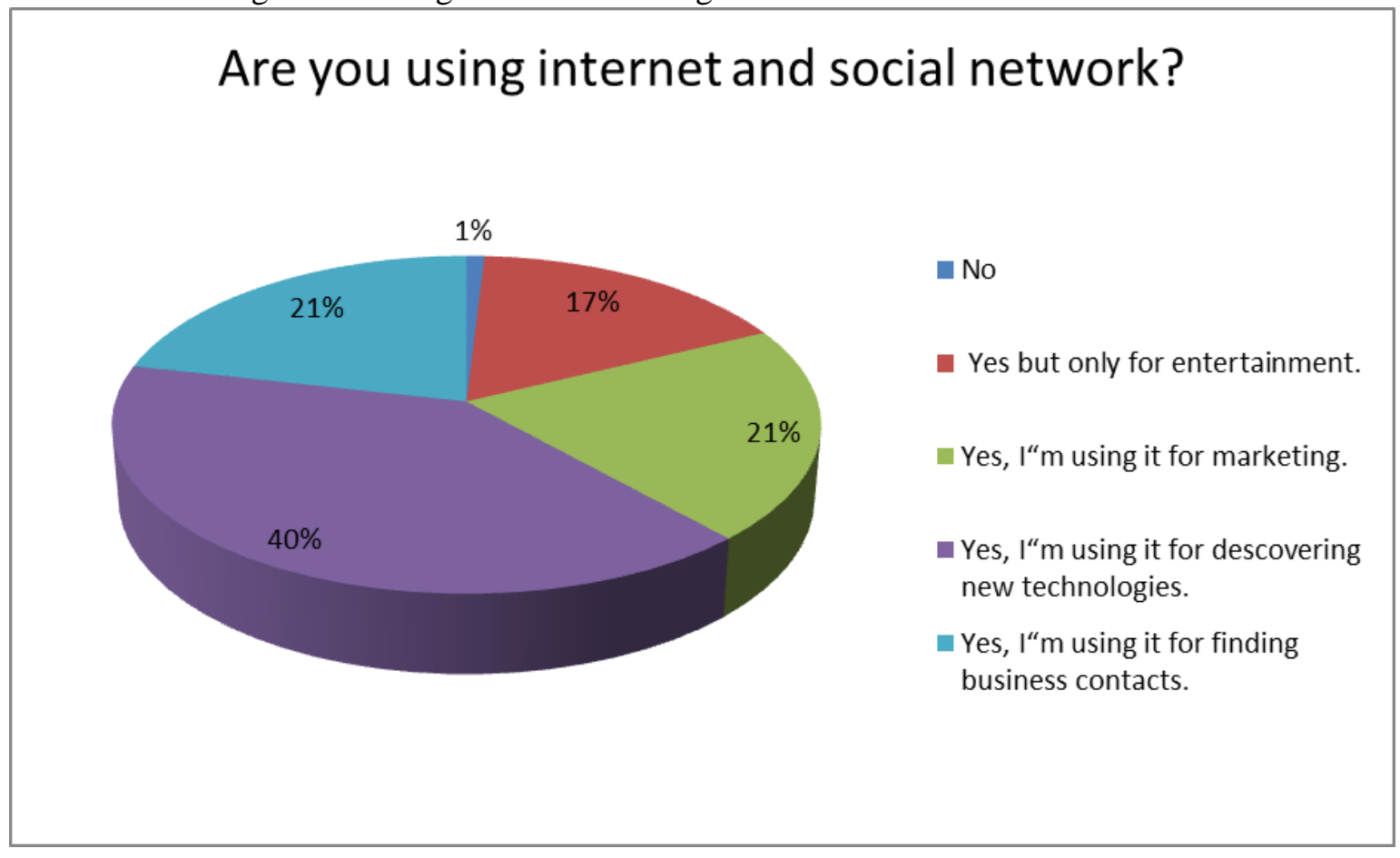

\section{If you had opportunity, what kind of knowledge would you want to access?}

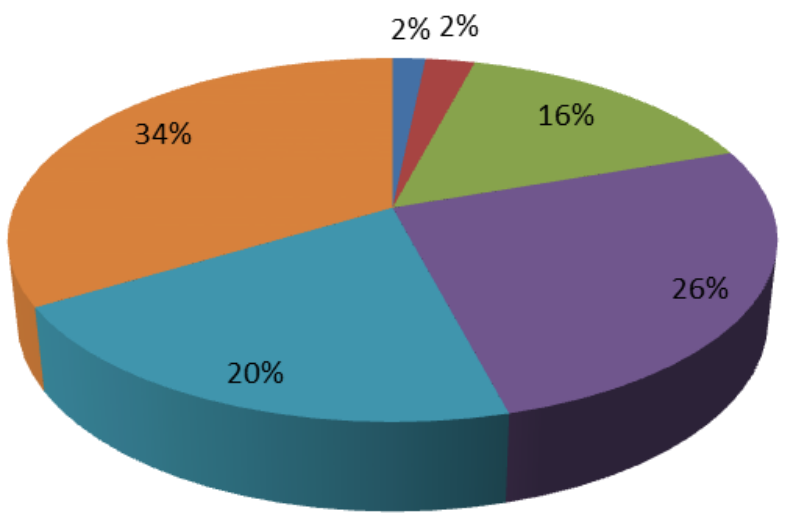

I was done studing in school. Rest I learn from experience.

- I am considering myself expert in my field, and could teach others instead.

Aspects of marketing and realisation.

- Agricultural and production boosting techniques.

These charts show, that most part of the little farmers are using internet for extending their knowledge and find new contacts in their business. And as research shows, it is their only way for it.

Based on the above, little farmers are not even interested on exporting their products and even they don't care about the quality of their products: 
$8^{\text {th }}$ International Conference on Management, Economics and

Humanities

Barcelona, Spain

\section{How would you rate quality of your product:}

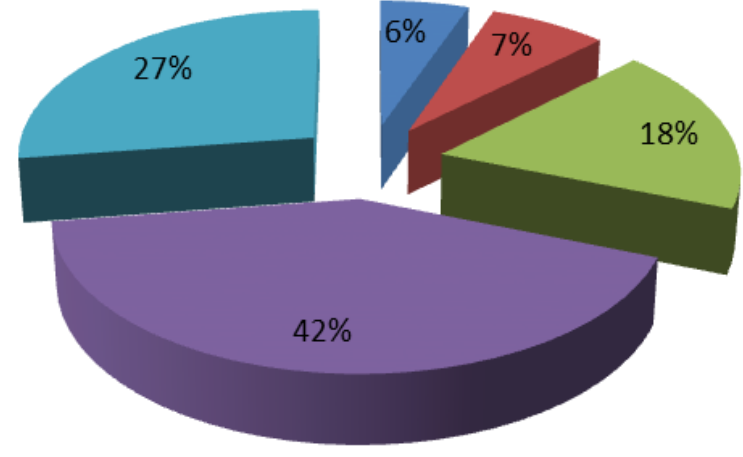

I“m producing whatever I manage to.

Average.

- It is a good product but it gets spoiled fast if I can"t sell it in time.

I am producing high quality products.

I am producing finest quality bio-products.

\section{Are you interested in export of your products?}

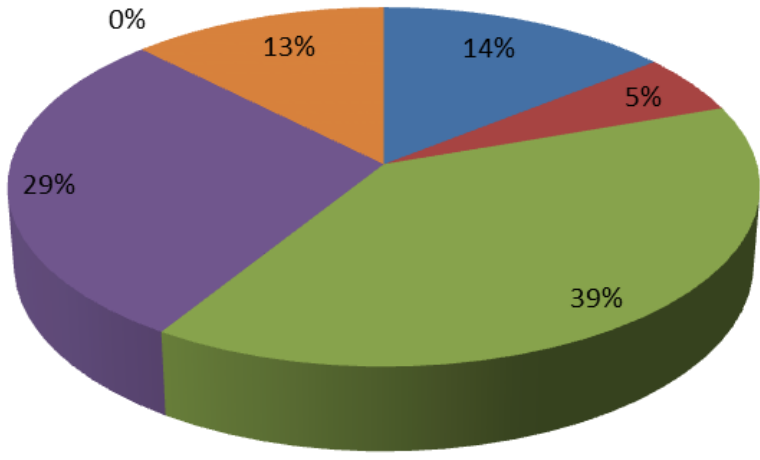

- It would be good, but I don"t think my product would be interesting.

n I would be satisfied just with tourists buing my product.

I am interested but I encounter problems for now.

I am interested and preparing for export at the moment.

- I am exporting already.

I am not interested in export. 


\section{What prevents you from export?}

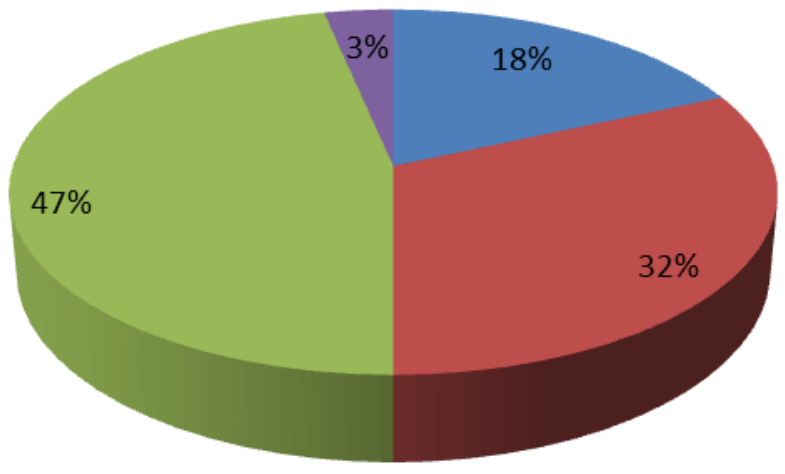

- I don"t have enough finances for export marketing.

- I don"t have contacts to manage delivery of product.

- I don"t have resourses to produce enough to fit export requirements.

- Bureaucracy and lack of assistance from the government

\section{Our Model of Regional Cluster}

On our works we have introduced the model of "Regional Clusters", which will give the opportunity to farmers find resources for the measures, such as:

- Diversification of markets in abroad

- Planning the production process according to the word market demands

- To raise awareness in the field

- Find new investments for further development

- Find new technologies and innovative methods: (Fig.2)

In the figure, Association is a farmer's union with pay method. But the money, they will collect, must not be the major investment for this union. These payments are for salary of few basic employees. The goals of the union will contain but not limited by

- Increasing of member's list

- Find new markets for export

- Write recommendations for the members about market changes

- Find sources for making trainings and researches about newest ways of agriculture, study new technologies and methods.

- Find finances and other resources for resolving the problems of members.

- Write projects and receive grants for implementation of ISO, HASSP and other international standards in the member organizations.

- Find international Partners and investors, for further development

- Help members and increase the coordination for collecting big batch of products for export, saving the quality and quantity of supply 


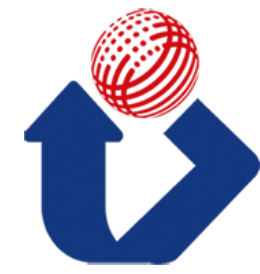

$8^{\text {th }}$ International Conference on Management, Economics and

Humanities

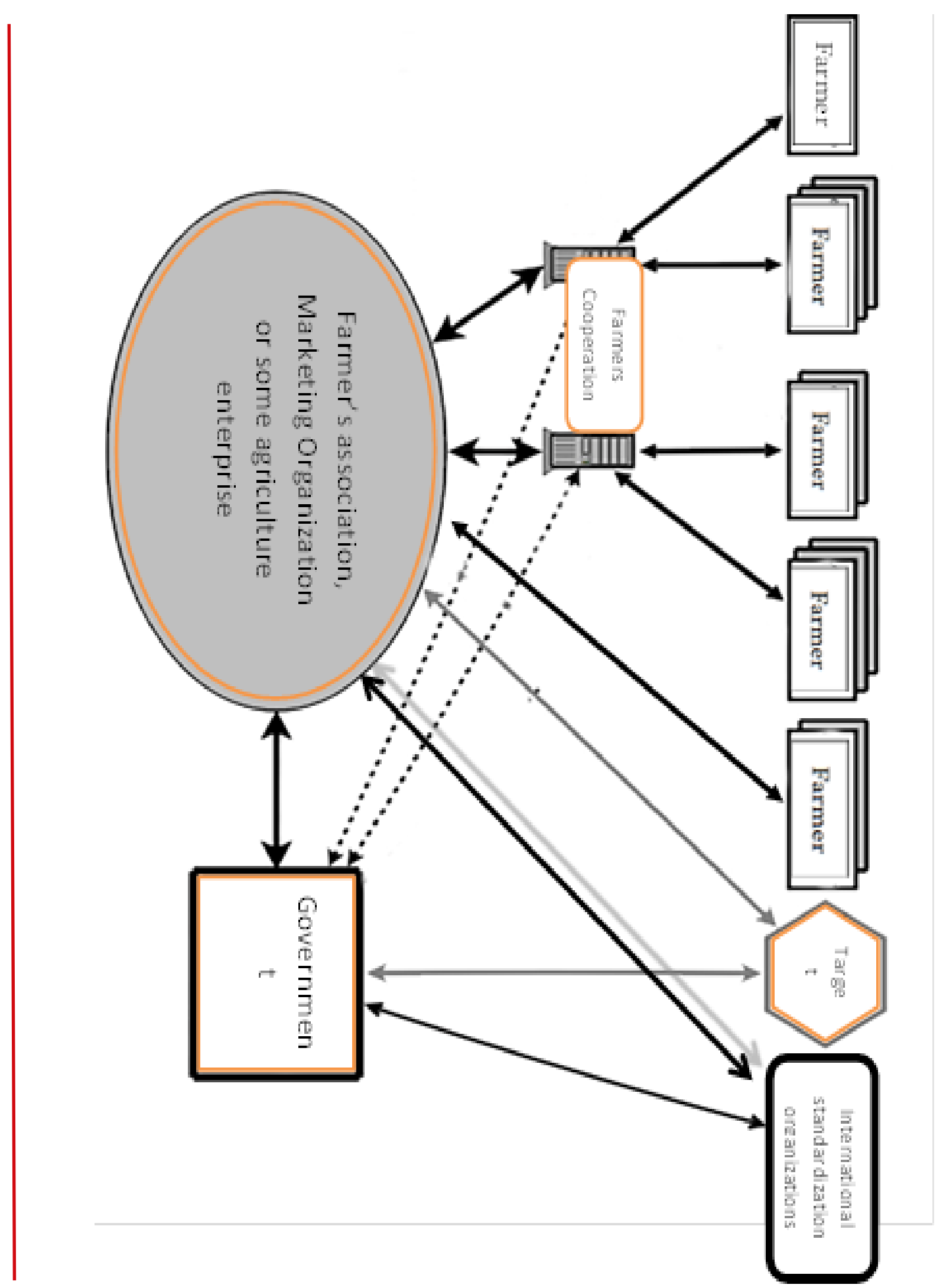


But these clusters will not be able to start enactment and become successful without startup help from Government, such as:

1. Tax benefits,

2. Preferences on government purchases and tenders.

3. Regional development can be prioritized the projects, which are initiated or submitted by the regional cluster.

4. Make some of international standards as a national law and Establish new laboratories and standardization organizations, which will help farmers to obtain export documentations.

Farmers and Cooperatives in the cluster don't have mutual obligation other then they will agree with each other. But the association must become the place of finding common interests with all or part of its members in the issues, such as:

- $\quad$ Forming a large batch for export

- Obtain the quality certificate

- Invite the experts of the field

- Implementation of new technics and technologies

- And other

For developing countries it is very important to have an agro-production, but for further development of economics is more convenient to produce and export not only primary products (fruit, vegetables) but already processed and manufactured products (juices, canned products and ets).

Besides the problems, clusters will resolve, to stimulate manufacturing in the country, governmental politic must help entrepreneurs to resolve few more difficulties:

1. There are big gaps in greenhouse field in Georgia and therefore supply of agro products is very seasonal. That is the reason of increasing spends for production and makes it unprofitable.

2. Most important problem is, that there is a conflict of interests between the producers and farmers. For Georgian farmers his harvest is the only source of income and of course wants to sell as high price, as possible, to be provided with dignified life. But manufacturers want to buy high quality product in low price to be competitive in market. In my opinion, this case government must resolve this case, as in European Union (as it was written above). - During first few years, government will subsidize the cost of some, most important agro product's price, if they will be sold for production.

3. And the last, but not least problem- government must stimulate the students study on the programs, market needs at this time. (Seems stupid, but in post-soviet countries there are list of prestigious programs, in which all of students want to study. For example justice, medicine and so on).

An important characteristic of the Georgian agricultural sector is the relative lack of vertical integration and the pre-eminence of small-scale production. The largest share of products, used by producers is bought from independent, small farmers on the market at the time of harvest. This gives rise to a range of problems:

1. As long-term delivery contracts are still highly infrequent, price are quite volatile. This can reinforce the lock-in on the current market; particularly prices are significantly higher when agricultural products can be sold in Russia - to the detriment of those producers attempting to enter the more price-competitive markets of the future.

2. Small farmers are often unable to invest in more modern production methods, leading to outdated, inefficient and labor intensive cultivation techniques and prices that are relatively high for a country with low wages and good natural conditions for plant growing.

3. Quality control over the plants is very hard to establish in market with hundreds of thousands of producers and little vertical integration. Small agro producers are very reluctant to allow factories and other producers to influence the varieties that they grow, their production techniques and harvest 
times, etc. While some small farmers do produce excellent homemade, but the resulting quantities are too small for commercial export.

A consolidation of such little farmers is unrealistic in the short run and would lead to difficult social considerations, although some larger exporters are gradually attempting to increase their own land production and should be encouraged to do so or they can initiate the regional cluster, to achieve more considerations, best quality product from suppliers and a big quantities of production for export.

To resolve these problems, it's important from government to make some actions for raising public awareness and participation in reform process. Farmers must be learned, how important is cooperation with each other and how many profit will take each of them with consideration of their resources.

\section{Conclusion}

In Georgia, as in other developing countries, it is very important, to find sources for collecting the resources in agricultural field, to have some competitiveness in the market.

As the researches show, clusters are good (maybe the best) solution especially in poor countries, but in such rural areas, little farmers do not have the knowledge needed to establish and manage a cluster.

Georgian agriculture is characterized by low productivity and weak competitiveness across most major agricultural sectors, the only way for producing competitive products for international market, is cluster cooperation. But to start such cooperation can only marketing or farming associations, which have qualified labor.

While the "Regional Clusters" are going to be successful, they would not be developed without government protection:

- It is important to offer farmers the charter pattern and start project funding for trainings about clusters, its benefits and rules for working under the "one umbrella";

- Governmental organizations to fund farmer's associations for making entrepreneurs register and these projects will develop to the commodity exchange.

- Projects which are initiated by the farmers unions, cooperatives or regional clusters must be preference in regional development plans and implemented for the first time. This means, that there will be the coordination between regional and agrarian politics and regional development will provide the labor for agrarian development.

All above cause the intensification of production in the field increase the competitiveness of agro producers and manufacturers. The strict quality control will increase the country's image, as a best quality producer and gives opportunity Georgian companies for diversification of their markets.

\section{References}

[1] Mikheil Tokmazishvili; George Berulava; Jacek Cukrowski; Kim Boermans; George Nanobashvili "Aid for Trade Needs Assessment - Georgia Trade and Human Development April 2011"

[2] LUCA CESARO, FRANCESCO MANTINO- WHAT IS TO CHANGE IN EU AGRICULTURAL POLICIES AFTER 2013? INTEGRATION, GREENING AND THE PROBLEM OF BUDGET REDUCTION. IVANE JAVAKHISHVILI TBILISI STATE UNIVERSITY,Bioeconomy and Sustainable Development of Agriculture, II International Scientific-Practical Conference proceedings.

[3] Nino Rukhaia-Mosemgvdlishvili - "Regional Clusters" -The Best Way for Georgian Farmers to adapt the Requirements of the European Market; "ECONOMICS " \# 5-6, 2015

[4] Nino Rukhaia-Mosemgvdlishvili - “,A stimulating export oriented policy of agricultural sector of developing countries on example of Georgia" -International Conference On Applied Economics (ICOAE 2018) . conference proceedings. 